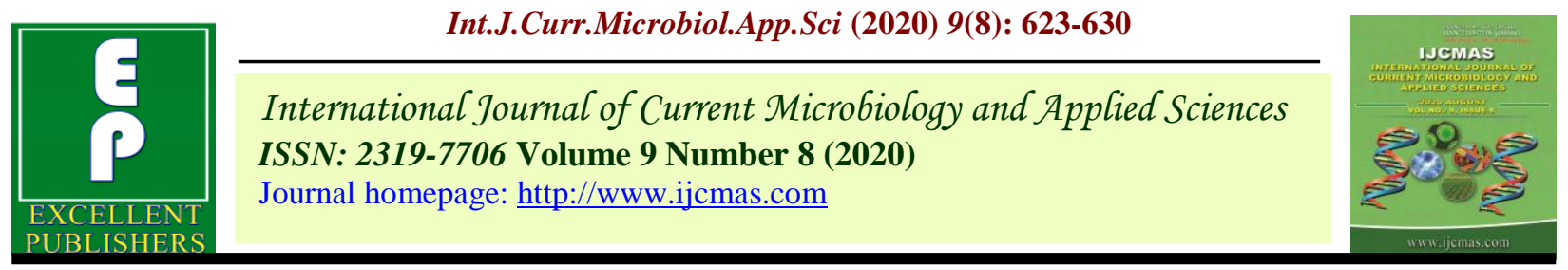

Original Research Article

https://doi.org/10.20546/ijcmas.2020.908.069

\title{
Studies on Biology of Drumstick Leaf Eating Caterpillar, Noorda blitealis, Walker
}

\author{
K. B. Rachana, S. B. Jagginavar* and H. T. Prakash \\ Department of Agricultural Entomology, College of Agriculture, Vijayapur, \\ UAS Dharwad Karnataka- 586101, India \\ *Corresponding author
}

\begin{abstract}
A B S T R A C T
Keywords

Biology, Noorda blitealis, Incubation period, Fecundity, Longevity etc

Article Info

Accepted:

10 July 2020

Available Online:

10 August 2020

Studies on biology of drumstick leaf eating caterpillar, Noorda blitealis, Walker was conducted in the laboratory, Department of Agricultural Entomology at College of Agriculture Vijayapur in the year 2018-19. Biology of Noorda blitealis Walker revealed that female moth laid the eggs singly at the ventral side of the leaf petiole and on the tip of the leaves rather than in cluster. The mean incubation period was $2.8 \pm$ 0.79 days. Caterpillar moulted four times and there were five larval instars were noticed during study. Total larval period was $12.9 \pm 1.85$ days, while pre-pupal and pupal period was $2.2 \pm 0.42$ and $8.1 \pm 1.37$ days, respectively. The fecundity was 96.7 \pm 5.65 eggs. Longevity of male moth was $6.3 \pm 1.06$ and $2.3 \pm 0.48$ days, while, female is $6.6 \pm 1.17$ and $3.0 \pm 0.82$ days with and without honey solution, respectively.
\end{abstract}

\section{Introduction}

The drumstick is a quick growing tree and attains a height of 8 to 12 meters. It is tolerant to drought and also adapted to diverse ecosystem and agriculture systems. It placed in an exclusive and constant place in vegetable production in India. The trunk is soft wood and branches are delicate which break down easily while plucking the pods. The leaves are tripinnate and leaflets elliptical; flowers are white, fragrant and are borne on large panicles. India is the lead producer of Moringa with an annual production of 2.20 to 2.40 million tonnes of tender fruits in an area of 38,000 ha leading to the productivity of around 63 tonnes per ha. Among the different states, Andhra Pradesh leads in both area and production $(15,665 \mathrm{ha})$ followed by Karnataka $(10,280 \mathrm{ha})$ and Tamil Nadu (13250ha). In other states, it occupies an area of 4,613ha (Sekhar, 2018).

In India drumstick is attacked by various insect pests, attacking at various stages of the tree. Among them the Leaf eating caterpillar, Noorda blitealis Walker is considered as a serious pest of moringa, it occurs throughout the year and causes severe crop damage (David and Kumarswamy, 1982). In severe 
conditions $N$. blitealis causes up to 100 per cent foliage loss. Early instars of $N$. blitealis scrape the chlorophyll content of leaves and causes into papery form, later on, different instars feed the leaves completely and leaving only veins behind. Female moth deposits creamy oval eggs on beneath the leaf surface, later larvae starts feeding on leaves by scrapping (Kalia and Joshi, 1997; Munj et al., 1998; Mahesh and Kotikal, 2014). With this background, the present study was taken up to study the Biology of drumstick defoliators.

\section{Materials and Methods}

The study on biology (Noorda sp.) on drumstick was conducted under laboratory condition at, College of Agriculture, Vijayapur. The larvae of defoliators were collected from the infested Moringa orchard. The collected larvae were reared in Petri plates and ventilated plastic jars with moringa leaves as a food to obtain the different developmental stages of the insect for morphological descriptions in replicated trial. The morphometric characters viz., length, breadth, shape, colour, structure of eggs studied under binocular microscope. The larval stages were determined based on the number of larval instars and castings up to the pupal stage. The larval length, breadth and head capsule of different instars were measured under microscope with an image analyzer.

Larval period was recorded as the number of days taken from hatching of egg till last instar larvae transformed into pupae. Pre-pupal period recorded as a period between the last instar larvae transformed before pupal period. Pupal period recorded from the date of pupation to till adult emergence. Male and female adults were kept in ventilated plastic jar $(0.095 \mathrm{~m}$ height $\times 0.115 \mathrm{~m}$ diameter $)$ to know the male and female adult longevity. The period from adult emergence to death of the adult was recorded as adult longevity. Longevity of adult was recorded both with and without food (Honey). Total life cycle was recorded from emergence of female moth till the death of adults emerged from the pupae.

\section{Results and Discussion}

The fecundity of female adult, Noorda blitealis ranged from 88 to 105 eggs per female with mean of $96.7 \pm 5.65$ eggs. The female laid single egg rather than in cluster on leaf petiole and lower side of the leaf tip. Freshly laid eggs were creamy, smooth and bead like structure it turns to yellow after one day and became brown while hatching. These mainly prefer the young terminal leaves for laying the eggs. The average incubation period was $2.8 \pm 0.79$ days which ranged from 2 to 4 days (Table 1). The length of freshly laid eggs varied from $0.43 \mathrm{~mm}$ to 0.74 $\mathrm{mm}$ with an average of $0.54 \pm 0.10 \mathrm{~mm}$ and breadth varied from $0.43 \mathrm{~mm}$ to $0.67 \mathrm{~mm}$ with an average of $0.52 \pm 0.06 \mathrm{~mm}$ (Table 2).

The present results were confirmatory with the findings of Nair (1975) reported that incubation period of Noorda blitealis Walker was usually three days. The present findings are contradictory with Munj et al., (1998) studied the biology of drumstick leaf eating caterpillar, N. blitealis. Eggs were deposited singly as well as in clusters of 26 to 84 on the under surface of the drumstick leaves and conformity with results that freshly laid eggs of $N$. blitealis were smooth, circular and yellowish white with an average incubation period of $N$. blitealis was 2.90 days. Abdalla et al., (2013) recorded that shape of the egg was oval and cream colour which was deposited by $N$. blitealis on drumstick plant. Similar with Kumari et al., (2015) recorded total number of eggs deposited by a female varied from 82 to 102 with an average fecundity was 89.60 and average incubation 
period was $2.8 \pm 0.83$ days. The variation in results may due to changes in climatic conditions, location of the study, availability of food etc.

The first instar larvae were light green in colour with yellowish red head capsule they more preferred underside of the young leaves. They were minute, sluggish and became active. They preferred young leaves for feeding and leaves became transparent papery and finally withered. Second instar larvae similar to first instar larvae in colour, structure with brownish red head capsule. They web the leaves and feed on green tissues of leaves with white blotches. Third instar larvae were larger than second larvae and these were yellowish green along with body hairs and brownish red head capsule. The fourth instar larvae were similar to third instar larvae with short body hairs. It was yellowish with brownish head capsule. The fifth instar larvae were smaller than fourth instar and light pink in colour with short hairs on body. Head capsule was brown in colour.

When larva completed its period it stopped feeding and development. It became sluggish and searched for suitable place for pupation. Larva produced sticky material to formed earthen cocoons for pupation. Length of the pre-pupa was short compared to fifth instar larvae. Pre-pupa was yellow and light brown in colour. The pupation occurs in earthen cocoons. The freshly formed pupa was soft and brown, which later turned into black. The pupa was oval in shape. The present findings are similar with Munj et al., (1998) who reported newly hatched first instar larva of $N$. blitealis was pale green initially which later on turned yellowish green with yellowish red head capsule. These findings are also in agreement with the results of Kumari et al., (2015) reported that newly hatched larva was pale green in colour. The head capsule was reddish and prothorasic shield was absent.
The body was covered with minute whitish hairs. Second instar larva was also pale green in colour. Third instar larva was pale yellowish with red tinge. Fourth instar larva was pale green with reddish head capsule. Fifth instar larva was yellowish green with yellowish red head capsule.

The larval period for first instar larva ranged from 1 to 3 days with an average of $1.9 \pm 0.75$ days, for second instar larva ranged from 2 to 3 days with an average of $2.7 \pm 0.48$ days, for third instar larva ranged from 2 to 4 days with an average of $3.1 \pm 0.75$ days, for fourth instar larva ranged from 2 to 4 days with an average $2.7 \pm 0.67$ days and for fifth instar larva ranged from 2 to 3 days with an average of $2.5 \pm 0.53$ days. The total larval period of leaf eating caterpillar, N. blitealis ranged from 12 to 17 days with an average of $12.9 \pm 1.85$ days. The pre-pupal period ranged from 2 to 3 days with average $2.2 \pm 0.42$ days. The pupal period ranged from 6 to 10 days with an average of $8.1 \pm 1.37$ days. Pre-oviposition period varied from 1 to 2 days with an average of $1.8 \pm 0.42$ days. Oviposition period varied from 2 to 5 days with an average of $3.6 \pm 0.96$ days (Table 1 ). The results were in accordance with the results obtained by Munj et al., (1998) reported that average duration of first, second, third, fourth and fifth instar larva was 1.64, 2.60, 2.40, 2.04 and 1.92 days, respectively and contracting with the results of total larval period was 8 to 14 days with an average of 10.68 days. It may due to climatic variations, location of the study etc. Similar with Kumari et al., (2015) reported that there were five larval instars and the average duration of first, second, third, fourth and fifth instar larva was $1.45 \pm 0.42,2.3 \pm 0.47,2.42 \pm 0.65,1.95 \pm$ 0.66 and $2.02 \pm 0.54$ days, respectively.

The body length of first instar larva varied from $1.23 \mathrm{~mm}$ to $2.58 \mathrm{~mm}$ with an average of $1.79 \pm 0.45 \mathrm{~mm}$ while the breadth varied from 
$0.13 \mathrm{~mm}$ to $0.45 \mathrm{~mm}$ with an average of 0.28 $\pm 0.11 \mathrm{~mm}$. The length of head capsule varied from $0.11 \mathrm{~mm}$ to $0.28 \mathrm{~mm}$ with an average of $0.18 \pm 0.06 \mathrm{~mm}$ and breadth of head capsule varied from $0.11 \mathrm{~mm}$ to $0.37 \mathrm{~mm}$ with an average of $0.20 \pm 0.09 \mathrm{~mm}$. The body length of second instar larva varied from $2.55 \mathrm{~mm}$ to $3.92 \mathrm{~mm}$ with an average of $3.30 \pm 0.39 \mathrm{~mm}$ while the breadth varied from $0.42 \mathrm{~mm}$ to $0.53 \mathrm{~mm}$ with an average of $0.48 \pm 0.05 \mathrm{~mm}$. The length of head capsule varied from 0.29 $\mathrm{mm}$ to $0.47 \mathrm{~mm}$ with an average of $0.38 \pm$ $0.06 \mathrm{~mm}$ and breadth of head capsule varied from $0.39 \mathrm{~mm}$ to $0.54 \mathrm{~mm}$ with an average of
$0.47 \pm 0.04$. The body length of third instar larva varied from $5.50 \mathrm{~mm}$ to $6.89 \mathrm{~mm}$ with an average of $6.43 \pm 0.42 \mathrm{~mm}$ while the breadth varied from $0.95 \mathrm{~mm}$ to $0.62 \mathrm{~mm}$ with an average of $1.41 \pm 0.21 \mathrm{~mm}$. The length of head capsule varied from $0.66 \mathrm{~mm}$ to $1.22 \mathrm{~mm}$ with an average of $0.91 \pm 0.19$ $\mathrm{mm}$ and breadth of head capsule varied from $0.72 \mathrm{~mm}$ to $1.17 \mathrm{~mm}$ with an average of 0.93 $\pm 0.15 \mathrm{~mm}$. The body length of fourth instar larva varied from $11.68 \mathrm{~mm}$ to $17.26 \mathrm{~mm}$ with an average of $14.70 \pm 2.21 \mathrm{~mm}$ while the breadth varied from $1.28 \mathrm{~mm}$ to $1.99 \mathrm{~mm}$ with an average of $1.62 \pm 0.22 \mathrm{~mm}$.

Table.1 Duration of life stages of leaf eating caterpillar, Noorda blitealis Walker reared under laboratory

\begin{tabular}{|l|c|c|}
\hline \multicolumn{3}{|c|}{ Duration(days)* } \\
\hline Insect stages & Mean \pm S.D. & Range \\
\hline Incubation period & $2.8 \pm 0.79$ & $2-4$ \\
\hline Larval period & & \\
\hline I instar & $1.9 \pm 0.75$ & $1-3$ \\
\hline II instar & $2.7 \pm 0.48$ & $2-3$ \\
\hline III instar & $3.1 \pm 0.75$ & $2-4$ \\
\hline IV instar & $2.7 \pm 0.67$ & $2-4$ \\
\hline V instar & $2.5 \pm 0.53$ & $2-3$ \\
\hline Total larval period & $12.9 \pm 1.85$ & $11-17$ \\
\hline Pre pupal period & $2.2 \pm 0.42$ & $2-3$ \\
\hline Pupal period & $8.1 \pm 1.37$ & $6-10$ \\
\hline Adult longevity & & \\
\hline Male without honey & $2.3 \pm 0.48$ & $2-3$ \\
\hline Male with honey & $6.3 \pm 1.06$ & $5-8$ \\
\hline Female without & $3.0 \pm 0.82$ & $2-4$ \\
\hline honey & & \\
\hline Female with honey & $6.6 \pm 1.17$ & $5-8$ \\
\hline Total life cycle & & \\
\hline Male & $32.3 \pm 1.77$ & $30-35$ \\
\hline Female & $32.6 \pm 2.91$ & $29-38$ \\
\hline Pre- oviposition & $1.8 \pm 0.42$ & $1-2$ \\
period & & \\
\hline Oviposition period & $3.6 \pm 0.96$ & $2-5$ \\
\hline Fecundity & $96.7 \pm 5.65$ & $88-105$ \\
\hline
\end{tabular}

*Mean of ten observations 
Table.2 Morphometrics of leaf eating caterpillar, Noorda blitealis Walker

\begin{tabular}{|l|c|c|c|c|}
\hline \multirow{2}{*}{} & \multicolumn{2}{|c|}{ Length $(\mathbf{m m}) *$} & \multicolumn{2}{c|}{ Breadth $(\mathbf{m m})^{*}$} \\
\hline Egg & Mean \pm S.D. & Range & Mean \pm S.D. & Range \\
\hline I instar & $0.55 \pm 0.10$ & $0.43-0.74$ & $0.52 \pm 0.07$ & $0.43-0.67$ \\
\hline II instar & $1.79 \pm 0.45$ & $1.23-2.58$ & $0.28 \pm 0.11$ & $0.13-0.45$ \\
\hline III instar & $3.30 \pm 0.39$ & $2.55-3.92$ & $0.48 \pm 0.05$ & $0.42-0.54$ \\
\hline IV instar & $14.7 \pm \pm 0.42$ & $5.50-6.89$ & $1.41 \pm 0.21$ & $0.95-0.62$ \\
\hline V instar & $10.88 \pm 2.70$ & $11.68-17.26$ & $1.62 \pm 0.22$ & $1.28-1.99$ \\
\hline Pre pupa & $8.91 \pm 1.86$ & $7.69-17.51$ & $1.74 \pm 0.29$ & $1.30-2.22$ \\
\hline Pupa & $8.60 \pm 0.84$ & $7.50-10.00$ & $1.38 \pm 0.38$ & $1.10-2.40$ \\
\hline Male & $9.45 \pm 0.83$ & $8.00-10.50$ & $17.20 \pm 1.25$ & $15.50-19.00$ \\
\hline Female & $11.15 \pm 0.78$ & $10.00-12.50$ & $17.70 \pm 0.86$ & $16.50-19.00$ \\
\hline
\end{tabular}

*Mean of ten observations

Table.3 Morphometrics of head capsule of leaf eating caterpillar, Noorda blitealis Walker

\begin{tabular}{|l|c|c|c|c|}
\hline \multirow{2}{*}{ Insect stage } & \multicolumn{2}{|c|}{ Length $(\mathbf{m m})^{*}$} & \multicolumn{2}{c|}{ Breadth $(\mathbf{m m}) *$} \\
\cline { 2 - 5 } & Mean \pm S.D. & Range & Mean \pm S.D. & Range \\
\hline I instar & $0.18 \pm 0.06$ & $0.11-0.28$ & $0.20 \pm 0.09$ & $0.11-0.37$ \\
\hline II instar & $0.38 \pm 0.06$ & $0.29-0.47$ & $0.47 \pm 0.04$ & $0.39-0.54$ \\
\hline III instar & $0.91 \pm 0.19$ & $0.66-1.22$ & $0.93 \pm 0.15$ & $0.72-1.17$ \\
\hline IV instar & $1.40 \pm 0.30$ & $1.01-1.89$ & $1.06 \pm 0.40$ & $0.46-1.71$ \\
\hline V instar & $1.19 \pm 0.25$ & $0.73-1.67$ & $1.13 \pm 0.19$ & $0.77-1.41$ \\
\hline Pre pupa & $0.90 \pm 0.46$ & $0.11-1.33$ & $0.96 \pm 0.51$ & $0.14-1.59$ \\
\hline
\end{tabular}

*Mean of ten observations

Fig.1 Experimental set up to study the biology of leaf eating caterpillar, Noorda blitealis walker
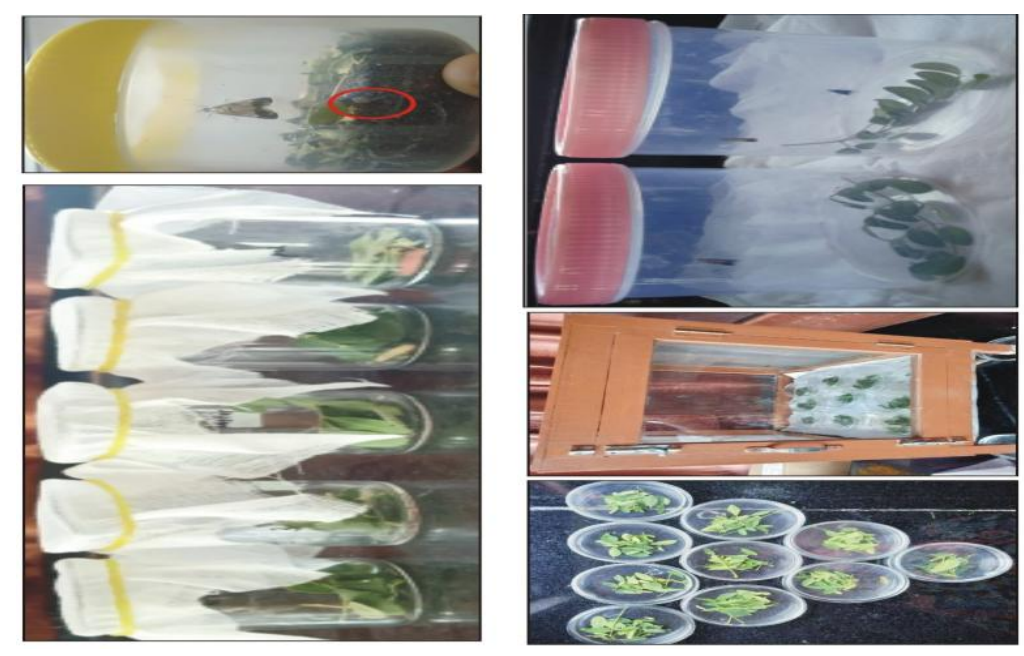
Fig.2 Life stages of leaf eating caterpillar, Noorda blitealis walker
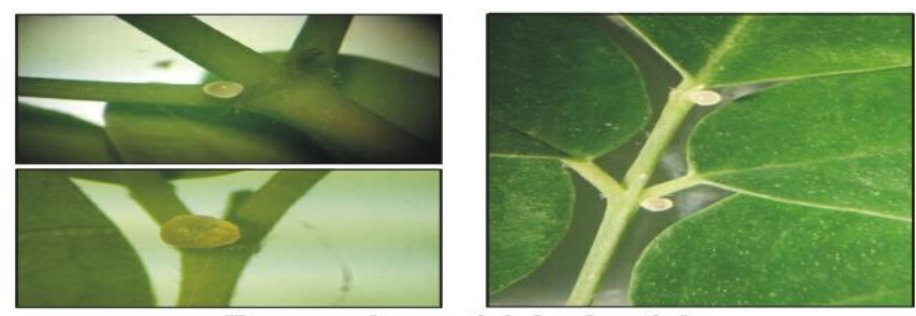

Eggs on drumstick leaf petiole
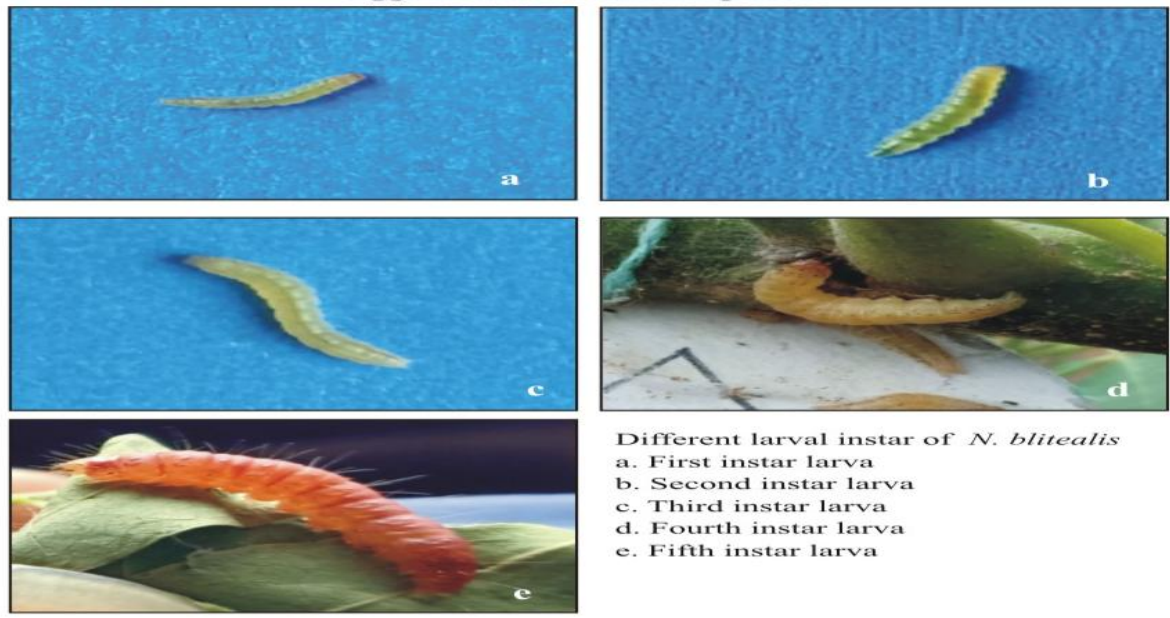

Different larval instar of $N$. blitealis

a. First instar larva

b. Second instar larva

c. Third instar larva

d. Fourth instar larva

e. Fifth instar larva

Fig.3 Life stages of leaf eating caterpillar, Noorda blitealis walker (cont......)

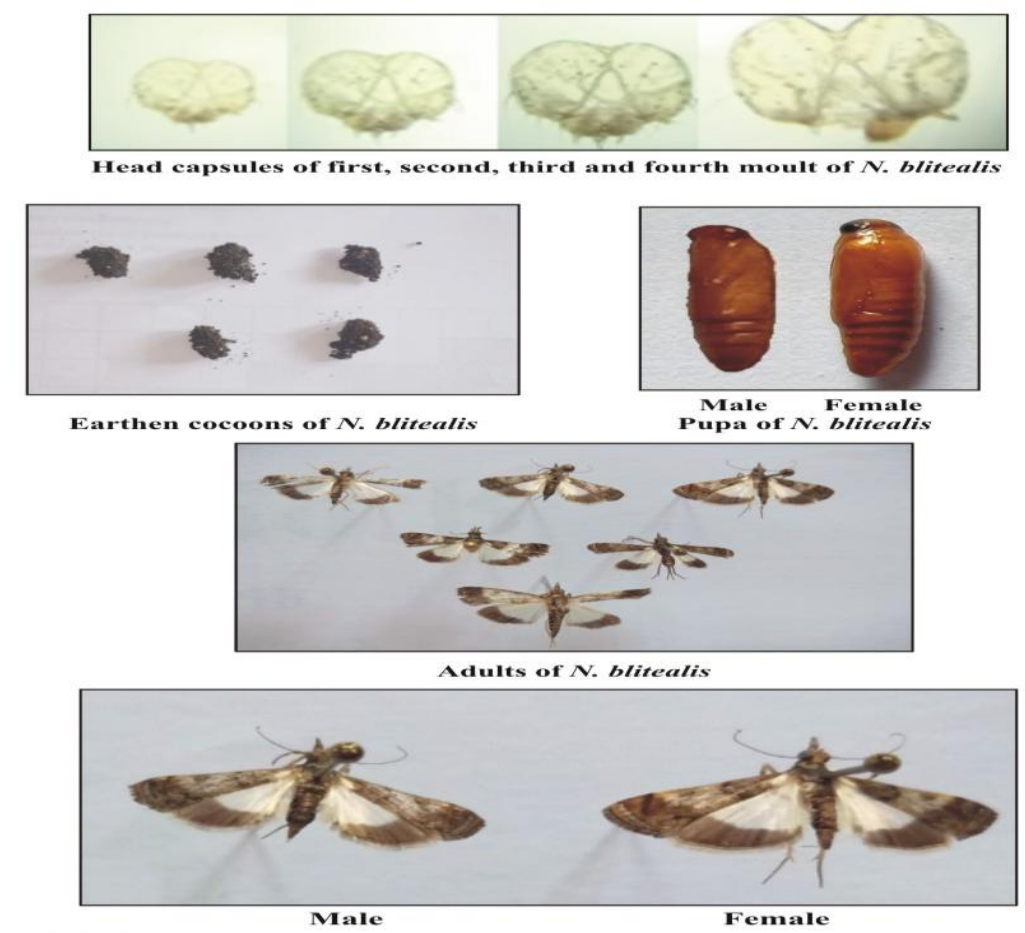


The length of head capsule varied from 1.01 $\mathrm{mm}$ to $1.89 \mathrm{~mm}$ with an average of $1.40 \pm$ $0.30 \mathrm{~mm}$ and breadth of head capsule varied from $0.46 \mathrm{~mm}$ to $1.71 \mathrm{~mm}$ with an average of $1.06 \pm 0.40 \mathrm{~mm}$. The body length of fifth instar larva varied from $8.69 \mathrm{~mm}$ to $17.51 \mathrm{~mm}$ with an average of $10.88 \pm 2.70 \mathrm{~mm}$ while the breadth varied from $1.30 \mathrm{~mm}$ to $2.22 \mathrm{~mm}$ with an average of $1.74 \pm 0.29 \mathrm{~mm}$. The length of head capsule varied from $0.73 \mathrm{~mm}$ to $1.67 \mathrm{~mm}$ with an average of $1.19 \pm 0.25$ $\mathrm{mm}$ and breadth of head capsule varied from $0.77 \mathrm{~mm}$ to $1.41 \mathrm{~mm}$ with an average of 1.13 $\pm 0.19 \mathrm{~mm}$. The length of pre-pupa varied from $7.21 \mathrm{~mm}$ to $12.23 \mathrm{~mm}$ with an average of $8.91 \pm 1.86 \mathrm{~mm}$ while the breadth varied from $1.10 \mathrm{~mm}$ to $2.40 \mathrm{~mm}$ with an average of $1.76 \pm 0.39 \mathrm{~mm}$. The length of head capsule varied from $0.11 \mathrm{~mm}$ to $1.33 \mathrm{~mm}$ with an average of $0.90 \pm 1.33 \mathrm{~mm}$ and breadth of head capsule varied from $0.14 \mathrm{~mm}$ to 1.59 $\mathrm{mm}$ with an average of $0.96 \pm 0.51 \mathrm{~mm}$. The length of pupa varied from $7.50 \mathrm{~mm}$ to 10.00 $\mathrm{mm}$ with an average of $8.60 \pm 0.84 \mathrm{~mm}$ while the breadth varied from $1.00 \mathrm{~mm}$ to $2.00 \mathrm{~mm}$ with an average of $1.38 \pm 0.38 \mathrm{~mm}$ (Table 2 and 3).

The present findings were on par with the findings of Munj et al., (1998) observed the length and width of fifth instar larva as 15.50 to $21.00 \mathrm{~mm}$ (Average $18.64 \mathrm{~mm}$ ) and 2.25 to $3.00 \mathrm{~mm}$ (Average $2.55 \mathrm{~mm}$ ), respectively similar with that pupal length ranged from $7.00 \mathrm{~mm}$ to $9.00 \mathrm{~mm}$ and pupal width ranged between $1.50 \mathrm{~mm}$ to $2.00 \mathrm{~mm}$. Abdalla et al., (2013) reported the egg of $N$. blitealis hatched into a tiny caterpillar, less than $3 \mathrm{~mm}$ in length. The body lengths of all instars ranged between 3-17 $\mathrm{mm}$. The average size (length $x$ width) of last instar larva was $16.0 \pm 0.4 \times 4.1$ $\pm 0.1 \mathrm{~mm}$ and average sizes (length $\times$ width) of pupa $8.7 \pm 0.6 \times 3.8 \pm 0.2 \mathrm{~mm}$

The moth of $N$. blitealis was medium in size with brownish forewings and hind wings were white in colour with brown coloured border. Thorax and abdomen were dark brown in colour with tapering end. Female moth was differentiated from male moth by abdomen and body which were bigger in size than male moth. Measurement of females shown that the length varied from $10.00 \mathrm{~mm}$ to $12.50 \mathrm{~mm}$ with an average of $11.15 \pm 0.78 \mathrm{~mm}$ while width across the expanded wings varied from $16.50 \mathrm{~mm}$ to $19.00 \mathrm{~mm}$ with an average of $17.70 \pm 0.86 \mathrm{~mm}$. In case of males the length varied from $8.00 \mathrm{~mm}$ to $10.50 \mathrm{~mm}$ with an average of $9.45 \pm 0.83 \mathrm{~mm}$ while, the width varied between $15.50 \mathrm{~mm}$ to $19.00 \mathrm{~mm}$ with an average of $17.20 \pm 1.25 \mathrm{~mm}$. Longevity of adults was studied by providing ten per cent of honey solution and without honey solution with fresh leaves of drumstick. The adult life duration was depended on food availability. Male adult longevity varied from 2 to 3 days with an average of $2.3 \pm 0.48$ days in the absence of honey solution and 5 to 8 days with an average of $6.3 \pm 1.06$ days in the presence of ten per cent of honey solution. While female adult longevity varied from 2 to 4 days with an average of $3.0 \pm 0.82$ days in the absence of honey solution and 6 to 8 days with an average of $6.6 \pm 1.17$ days in the presence of ten per cent of honey solution (Table 2). The results are in contrary with the results obtained by Munj et al., (1998) studied female moth of $N$. blitealis was survived for 11.00 to 23.00 days while male moth survived for 6.00 to 13.00 days. Similar with Kumari et $a l$. , (2015) recorded the longevity of the male moth was 4 to 9 days with an average of 6.25 days with ten per cent honey solution and that of female moths was 7 to 20 days with an average of 11.70 days. This variation is due to food availability, weather parameters and variation of study location.

The life cycle of male moth was completed in to 35 days with an average of $32.3 \pm 1.77$ days. Female was completed in 30 to 38 days with an average of $32.6 \pm 2.91$ days. The 
present findings are on par with the findings of Munj et al., (1998) studied life cycle of $N$. blitealis Walker it was from egg to adult emergence ranged from 19 to 30 days with an average of 24.03 days.

\section{References}

Abdalla, A. S., Osman, E. N., Amna, F. and Faisal, E. A., 2013, New record and preliminary bio-ecological studies of the leaf caterpillar, Noorda blitealis walker (lepidoptera: pyralidae) in Sudan. Int. J. Sci. Nat., 4(1): 57-62.

David, B. V. and Kumarswamy, T., 1982, Elements of Economic Entomology. Popular book depot. Madras, pp. 356.

Kalia, S. and Joshi, K. C., 1997, Efficacy of foliar spraying of three varietal strains of Bacillus thuringiensis against the moringa defoliator Noorda blitealis Tams. (Lepidoptera: Pyralidae). Indian J. Plant Prot., 25(1): 65- 66.

Kumari, M. S. B., Kotikal, Y. K., Narabenchi,
G. and Nadaf, A. M., 2015, Bioefficacy of insecticides, botanicals and biopesticide against the leaf eating caterpillar, Noorda blitealis Walker on drumstick. Karnataka J. Agric. Sci., 28 (2): 193-196.

Mahesh, M. and Kotikal, Y. K., 2014, Studies on insect pests of drumstick, Moringa oliefera Lamk. Indian J. Plant Prot., 42: 461-464.

Munj, A. Y., Patil, P. D. and Godase, S. K., 1998, Biology of drumstick leaf eating caterpillar, Noorda blitealis Walker. Pestology, 22: 18-21.

Nair, M. R. G. K., 1975, Pests of drumstick. Insects and Mites of crops in India. ICAR, New Delhi, p. 404.

Sekhar C, Venkatesan N, Vidhyavathi A and Murugananthi M., 2018, Factors influencing moringa cultivation in Tamil Nadu - an economic analysis. Horticult. Int. J. 2(5):223-230.

\section{How to cite this article:}

Rachana, K. B., S. B. Jagginavar and Prakash, H. T. 2020. Studies on Biology of Drumstick Leaf Eating Caterpillar, Noorda blitealis, Walker. Int.J.Curr.Microbiol.App.Sci. 9(08): 623630. doi: https://doi.org/10.20546/ijcmas.2020.908.069 